\title{
Pasture legumes for the drought-prone, outwash soils of the southern Mackenzie Basin
}

\author{
R.F. WOODMAN ${ }^{1 *}$, J.M. KEOGHAN ${ }^{2}$ and B.E. ALLAN ${ }^{2}$ \\ 'AgResearch, Invermay Agricultural Centre, $P B$ 50034, Mosgiel \\ ${ }^{2}$ AgResearch Lincoln, PO Box 60, Lincoln \\ *Present address: 8, Beaconsfield Road, Portobello. Dunedin
}

\begin{abstract}
The persistence of lucerne (Medicago sativa L.), red clover (Trifolium pratense L.), birdsfoot trefoil (Lotus corniculatus L.) and perennial lupin (Lupinuspolyphyllus Lindley), overdrilled with and without companion grasses, was compared at a site representative of dry, acidic, outwash soils in the southern Mackenzie Basin, South Island. Plant populations were monitored for 9 years and legume seedling regeneration and stand recruitment were examined over three consecutive years under grazing by sheep and cattle. Pcrcnnial lupin was the best adapted legume species. Stand density increased by re-seeding. In contrast, few seedlings of birdsfoot trefoil developed as a result of reseeding, and survival of birdsfoot trefoil was generally restricted to the more favourable areas of the mosaic of soil. Red clover did not persist, and the few plants of lucerne that survived lacked vigour. Tall oat grass and cocksfoot showed good vigour and persistence across the mosaic of soil; smooth brome performed well and spread within

fertiliser application. However, traditional legumes are insufficiently drought tolerant to persist on droughty, less-fertile soils of the southern Mackenzie Basin (Woodman et $\boldsymbol{a l}$. 1992), and lucerne rooting depths are restricted by high levels of soluble aluminium (Douglas 1985 ) in the subsoil. Birdsfoot trefoil and perennial lupin are deep-rooted, drought-tolerant pasture legumes (Scott \& Charlton 1983; Davis 1991), offering a more reliable option on these soils. However, runholders have reported difficulties in maintaining satisfactory stands of birdsfoot trefoil. In contrast, perennial lupin is well adapted to depleted grasslands in the mid to higher rainfall (e.g., $>650 \mathrm{~mm} / \mathrm{annum}$ ) areas of the South Island high country (Scott 1989) and despite a lower feeding value (Scottet al. 1994). perennial lupin can significantly increase soil nitrogen at low phosphor\& levels compared with traditional legumes and birdsfot trefoil (Davis 1991).

This paper examines the long-term, persistence of a range of legumes with and without companion grasses and seedling recruitment, following overdrilling into hawkweed infested, infertile, acidic, outwash soils in the drought-prone southern Mackenzie Basin.
\end{abstract} the more favourable areas. From these results, perenniallupin,tall-oat-grass-and cocksfoot appear to be the best species available for the future development of sustainable pastoral systems in drought-prone outwash landscapes in the Mackenzie Basin.

K eywords: dryland, establishment, Lotus corniculatus, Lupinus polyphyllus, outwash soils, pasture legumes, persistence, seedling recruitment

\section{Introduction}

There are over 155000 ha of moraines, fans, terraces and flood plains in the Upper Waitaki Basin south of Lake Tekapo, $50 \%$ of these having stony soils of low water-holding capacity and low productive potential (Webb 1992). In the past, pasture improvement on these soils has been based on oversowing or overdrilling using traditional legume and grass mixtures such as white, red and alsike clovers and cocksfoots, with associated

\section{Methods and materials}

\section{Site description}

The experimental site was located on the outwash plains at Omarama Station (465 $\mathrm{m} \mathrm{asl}$ ) in the dry sub-humid environment of the southern Mackenzie Basin. The mean annual rainfall is around $520 \mathrm{~mm}$, but over a 40 . year period this has ranged from 338 to $782 \mathrm{~mm}$. The soils are from the Mackenzie series and described as a moderate to strongly leached yellow-brown shallow and stony soil (Webb_1992). Mackenzie-soils encompassa wide variation in stoniness, depth and texture phases. Stony phases occur on ridges or on sides of old stream channels with moderately deep alluvial phases within the channels. Soil characteristics are presented in Table 1. Natural ground cover at the start of the experiment consisted of hawkweed 50-70\% with 20 $30 \%$ bareground and the remainder sheep's sorrel, adventive grasses and a small component of native species. 
Table 1 Chemical composition of soils ar the trial area.

\begin{tabular}{|c|c|c|c|c|c|c|}
\hline \multirow{2}{*}{$\begin{array}{l}\text { Year } \\
\text { Depth (mm) } \\
\text { Location }\end{array}$} & \multicolumn{2}{|c|}{ 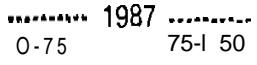 } & \multicolumn{4}{|c|}{ 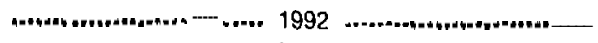 } \\
\hline & Across & trial site & Within & stream & channels & Outside stream channels \\
\hline $\mathrm{pH}(\mathrm{H}, \mathrm{O}) 1.2 .5$ & 5.7 & 5.3 & & 5.6 & & 5.3 \\
\hline Olsen $P(\mu g / g)$ & 34 & 23 & & 35 & & 39 \\
\hline Extractable sulphate $(\mu \mathrm{g} / \mathrm{g})$ & 3 & 3 & & 31 & & 12 \\
\hline Exchangeable $\mathrm{Ca}^{t}$ cations & 3 & 1 & & 4 & & 2 \\
\hline Exchangeable $\mathbf{K}^{\dagger}$ cations & 9 & 7 & & 11 & & 7 \\
\hline Exchangeable $\mathrm{Mg}^{\dagger}$ cations & 12 & 10 & & 10 & & 7 \\
\hline Exchangeable $\mathrm{Na}^{\mathrm{t}}$ cations & 2 & 1 & & 1 & & 2 \\
\hline Extractable Aluminium $\left(0.01 \mathrm{CaCl}_{2}\right)(\mu \mathrm{g} / \mathrm{g})$ & 4 & 10 & & 3.4 & & 6.7 \\
\hline
\end{tabular}

t MAF Quick Tests.

Approximate conversion factor to m.e.ll00 g soil (Cornforth 1984).

$\begin{array}{llll}\mathrm{C} a & \mathrm{~K} & \mathrm{Mg} & \mathrm{Na} .\end{array}$

$\begin{array}{llll}0.955 & 0.07 & 0.048 & 0.0217\end{array}$

Table 2 Sowing rates of legumes and grasses and seedling establishment numbers in November 1987 (8 weeks after sowing).

\begin{tabular}{|c|c|c|c|c|c|c|c|}
\hline Legumes & $\begin{array}{l}\text { Sowing } \\
\text { rate } \\
\mathrm{kg} / \mathrm{ha}\end{array}$ & $\begin{array}{c}\text { Seedling } \\
\text { numbers/m² } \\
(1987)\end{array}$ & $\begin{array}{l}\% \text { seedlings } \\
\text { from viable } \\
\text { seed sown }\end{array}$ & Grasses & $\begin{array}{l}\text { Sowing } \\
\text { rate } \\
\mathrm{kg} / \mathrm{ha}\end{array}$ & $\begin{array}{r}\text { Seedling } \\
\text { numbers } / \mathrm{m}^{2} \\
(1987)\end{array}$ & $\begin{array}{l}\% \text { seedlings } \\
\text { from viable } \\
\text { seed sown }\end{array}$ \\
\hline $\begin{array}{l}\text { Dryland birdsfoot } \\
\text { trefoil } \\
\text { Lotus corniculatus } \\
\text { (New Zealand) }\end{array}$ & 4 & 102 & 38 & $\begin{array}{l}\text { Grasslands Kara } \\
\text { cocksfoot }\end{array}$ & 4 & 99 & 23 \\
\hline $\begin{array}{l}\text { Grasslands Goldie } \\
\text { Lotus corniculatus } \\
\text { (New Zealand) }\end{array}$ & 4 & 69 & 24 & $\begin{array}{l}\text { Grasslands Maru } \\
\text { phalaris }\end{array}$ & 4 & 68 & 37 \\
\hline $\begin{array}{l}\text { Empire } \\
\text { Lotus corniculatus } \\
\text { (USA) }\end{array}$ & 4 & 60 & 21 & $\begin{array}{l}\text { Grasslands Hakari } \\
\text { mountain brome }\end{array}$ & 15 & 61 & 48 \\
\hline $\begin{array}{l}\text { Granger } \\
\text { Lotus corniculatus } \\
\text { (USA) }\end{array}$ & 4 & 34 & 13 & $\begin{array}{l}\text { Grasslands Tiki } \\
\text { smooth brome }\end{array}$ & 10 & 57 & 31 \\
\hline $\begin{array}{l}\text { Grasslands Pawera } \\
\text { red clover } \\
\text { (Trifoliumpratense) }\end{array}$ & 5 & 39 & 31 & $\begin{array}{l}\text { Grasslands Roa } \\
\text { tail fescue }\end{array}$ & 12 & 44 & 14 \\
\hline $\begin{array}{l}\text { Connie } \\
\text { perennial lupin } \\
\text { (Lupinus polyphyllus) }\end{array}$ & 10 & a & 26 & $\begin{array}{l}\text { Grasslands Matua } \\
\text { prairie grass }\end{array}$ & 15 & 18 & 19 \\
\hline \multirow{2}{*}{$\begin{array}{l}\text { WL318 } \\
\text { lucerne } \\
\text { (Medicago sativa) }\end{array}$} & a & 46 & 17 & $\begin{array}{l}\text { Tall oat grass } \\
\text { (Mackenzie selection) }\end{array}$ & 6 & 38 & 57 \\
\hline & SED & 7.0 & & & SED & 4.9 & \\
\hline
\end{tabular}

\section{Experimental}

The 5.1 ha trial area was overdrilled with a conventional triple disc drill in September 1987. The seven legumes and seven grasses listed in Table 2 were cross-drilled separately so that each legume and each grass was factorially combined within a fully randomised block design with three replicates. Legume seed was inoculated with the recommended strain of rhizobia and sown within 1 day of inoculation. except perennial lupin which received no inoculum. Molybdenised maxi-sulphur superphosphate fertiliser (50\% S. $5 \%$ P) was drilled at sowing at $250 \mathrm{~kg} / \mathrm{ha}$. The trial received no further fertiliser.

The trial is part of a 93 ha development block with no internal sub-division fencing, and is mob-grazed by sheep or cattle in late autumn and winter (as standing maintenance feed), and to a lesser extent in early spring as required by the Omarama Station management.

\section{Measurements}

Plant numbers of all sown legumes and grasses per unit area were counted in November each year. Twenty 
$0.25 \mathrm{~m}^{2}$ quadrat samples, selected at random in each $342 \mathrm{~m}^{2}$ plot, were recorded at each sampling.

Seedlings of birdsfoot trefoil and perennial lupin established by re-seeding, were counted each autumn (May) and spring (October) during the period 19931996, from four $25 \mathrm{~m}^{2}$ permanent quadrats in each $2400 \mathrm{~m}^{2}$ legume main plot. In addition, within each quadrat 25 lupin seedlings were chosen at random and marked with a coloured wire in October 1993 and assessed for survival and successful nodulation in the following December, May and October. Because of the low levels of available soil $N$, seedlings that were nonnodulated were small and yellow, or dead.

Daily rainfall measurements were recorded $1 \mathrm{~km}$ from the site at Tara Hills High Country Research Station (Table 3). Gravimetric soil moisture measurements $(0-$ $75 \mathrm{~mm}$ ) and soil temperatures at $100 \mathrm{~mm}$ depth were taken at weekly intervals in a dry spring and early summer period in 1993 (Figure 1).

Statistical analyses of legume and grass plant numbers were carried out by an analysis of variance using the statistical package Genstat according to the design of the experiment.
Table 3 Seasonal rainfall at Tara Hills High Country Research Station, Omarama for period 1987-1996.

\begin{tabular}{|c|c|c|c|c|}
\hline \multirow[b]{2}{*}{ Year } & \multicolumn{4}{|c|}{$\ldots$} \\
\hline & Summer & Autumn & Spring & Annual \\
\hline 1987 & 191 & 216 & 158 & 668 \\
\hline 1988 & 156 & 75 & 175 & 480 \\
\hline $\begin{array}{l}1989 \\
1990\end{array}$ & $\begin{array}{r}95 \\
207\end{array}$ & 176 & $\begin{array}{l}32 \\
97\end{array}$ & 490 \\
\hline $\begin{array}{l}1990 \\
1991\end{array}$ & $\begin{array}{l}207 \\
126\end{array}$ & $\begin{array}{c}162 \\
81\end{array}$ & $\begin{array}{r}97 \\
136\end{array}$ & $\begin{array}{l}490 \\
541\end{array}$ \\
\hline 1992 & 82 & 50 & 81 & 396 \\
\hline 1993 & 84 & 142 & 80 & 522 \\
\hline 1994 & 288 & 137 & 182 & 670 \\
\hline 1995 & 77 & 154 & 194 & 654 \\
\hline 1996 & 301 & 200 & & \\
\hline \multirow[t]{2}{*}{40 year mean } & 147 & 141 & 133 & 526 \\
\hline & \multicolumn{4}{|c|}{ Evaporation' } \\
\hline 30 year mean & 655 & 471 & 565 & 1691 \\
\hline
\end{tabular}

Evaporation rates taken from a below-ground dish-pan evaporation.

\section{Results}

Establishment and persistence

The initial establishment of legumes and grasses 8 weeks after sowing was good (Table 2). Although numbers of perennial lupin were less than those of other legumes (8

Figure 1 Soil moisture measurements $(0-75 \mathrm{~mm})$ and soil temperatures $(100 \mathrm{~mm})$ in spring and early summer 1993.

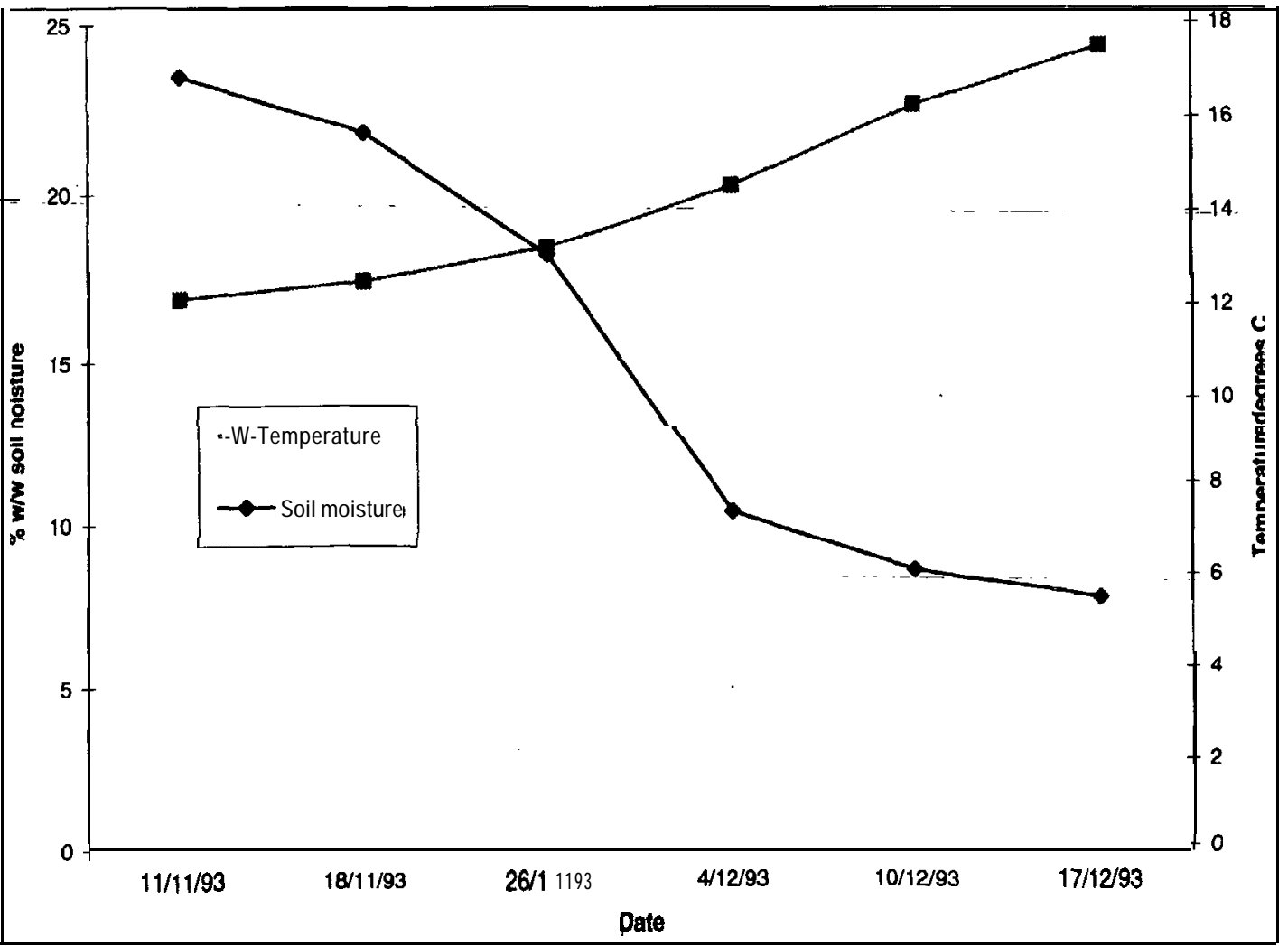


seedlings $/ \mathrm{m}^{2}$ compared with a mean of 66 birdsfoot trefoil seedlings $/ \mathrm{m}^{2}, 46$ lucerne seedlings $/ \mathrm{m}^{\prime}$. and 39 red clover seedlings $\left./ \mathrm{m}^{\prime}\right)$. percentage of lupin seedlings from viable seed sown was similar to those of the other legumes. Good establishment of legumes was followed by substantial plant losses by 1989-90. especially in perennial lupin (based on a percentage of initial establishment numbers). Thereafter plant losses continued at a slower rate of decline with the exception of perennial lupin, in which no decline in plant densities occurred after 1989. and during the period 1993 to 1995 the population of healthy lupin plants increased 6-fold.

Legumes with the best persistence 9 years after the start of the experiment were perennial lupin, Dryland, Grasslands Goldie and Granger birdsfoot trefoil (Figure 2). After 9 years, only a few Empire birdsfoot trefoil and yellowed, spindly lucerne plants remained and no red clover plants survived.

There was no significant effect of different grasses on legume stand densities throughout the experimental period. Of the grasses, tall oat grass and cocksfoot persisted best and grew vigorously across the mosaic of soils, although smooth brome performed well and spread within the more favourable areas (Figure 3). Observations indicated that birdsfoot trefoil plants grown with cocksfoot were less vigorous than those sown with other grass species.

\section{Legume re-seeding}

Seedling perennial lupin plants, recruited by re-seeding from the parent plants. were recorded in all years for which data were collected (Table 4).

Data collection began in autumn 1993. and included the dry 1993 spring for which soil moisture and temperature data were monitored (Figure 1). The vast majority of seedlings that survived to December survived until the next October (Figure 4). On the unfavourable soils outside the stream channels (Table 1), the establishment of re-seeded perennial lupin was less (e.g., replicate 3. Figure 4). although good numbers survived across the entire soil landscape mosaic and across grass companion species. By contrast. the very few seedlings recruited by
Figure 2 Sown legume plant numbers $\left(/ \mathrm{m}^{2}\right)$ for the period 1989-1995.

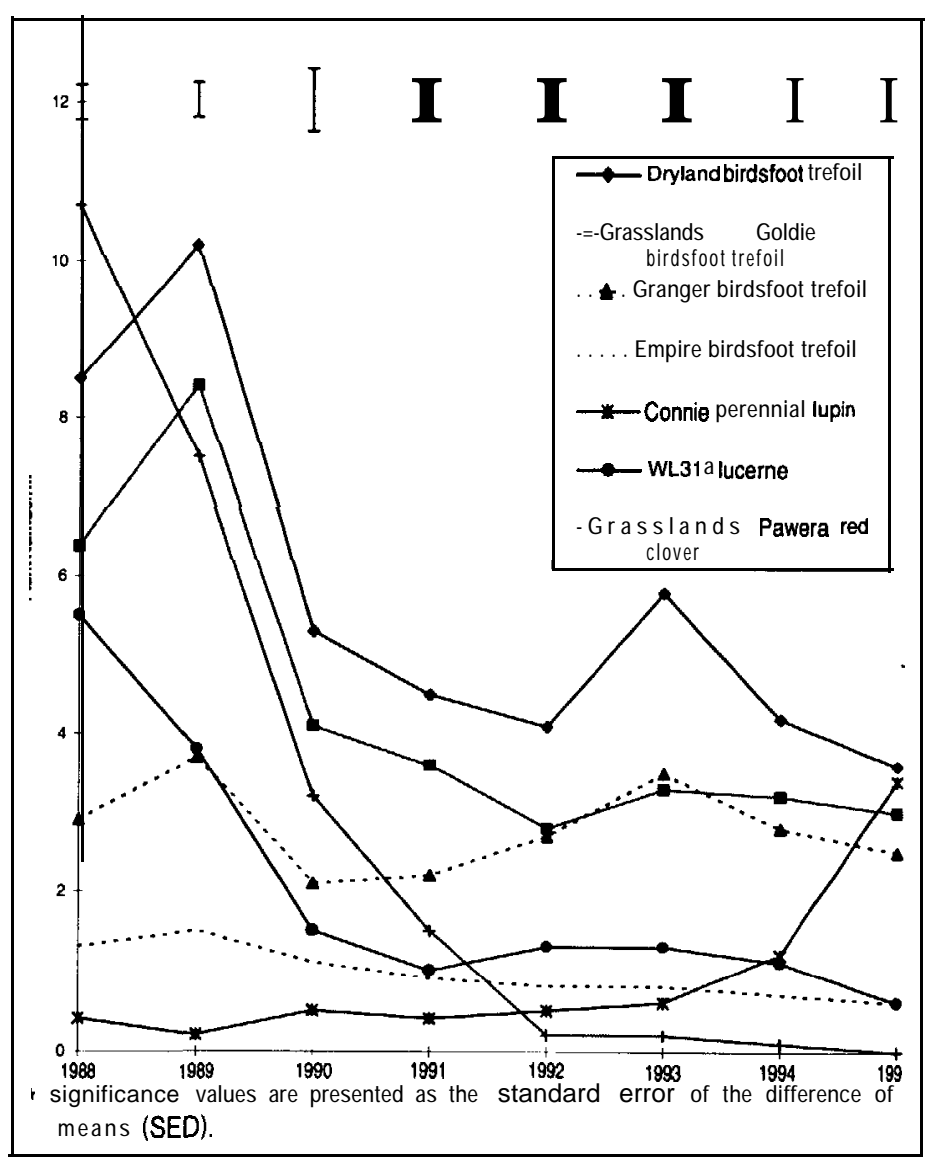

Table 4 Re-seeded seedling numbers $\left(/ \mathrm{m}^{2}\right)$ of Goldie, Dryland, Granger, Empire $L$ corniculatus, and perennial lupin.

\begin{tabular}{|c|c|c|c|c|c|c|c|}
\hline \multirow{2}{*}{$\begin{array}{l}\text { Year } \\
\text { Season }\end{array}$} & \multicolumn{2}{|c|}{$\ldots . . . \cdot 1993+\ldots$} & \multicolumn{2}{|c|}{-1994} & \multicolumn{2}{|c|}{-1995} & \multirow{2}{*}{$\begin{array}{r}1996 \\
\text { autumn }\end{array}$} \\
\hline & autumn & spring & autumn & spring & autumn & spring & \\
\hline Goldie & 0 & 0 & 0 & 0 & 0 & 0.33 & 0.05 \\
\hline Dryland & 0 & 0 & 0 & 0 &, 0 & 0.13 & 0 \\
\hline Granger & 0 & 0 & 0 & 0 & 0 & 0.06 & 0 \\
\hline Empire & 0 & 0 & 0 & 0 & 0 & 0 & 0 \\
\hline Lupin & 0.31 & 3.50 & 0.23 & 0.97 & 0 & 0.66 & 0.20 \\
\hline
\end{tabular}

re-seeding in birdsfoot trefoil were restricted to spring 1995 (Table 4). None of these seedlings survived.

\section{Discussion}

The outstanding result was the ability of Connie perennial lupin to develop into large, healthy stands and spread across the entire landscape mosaic. This was in contrast to the distribution of birdsfoot trefoil and the few remaining lucerne plants, for which survival was 
Figure 3 Sown grass plant numbers $\left(/ \mathrm{m}^{2}\right)$ for the period 1989-1993.

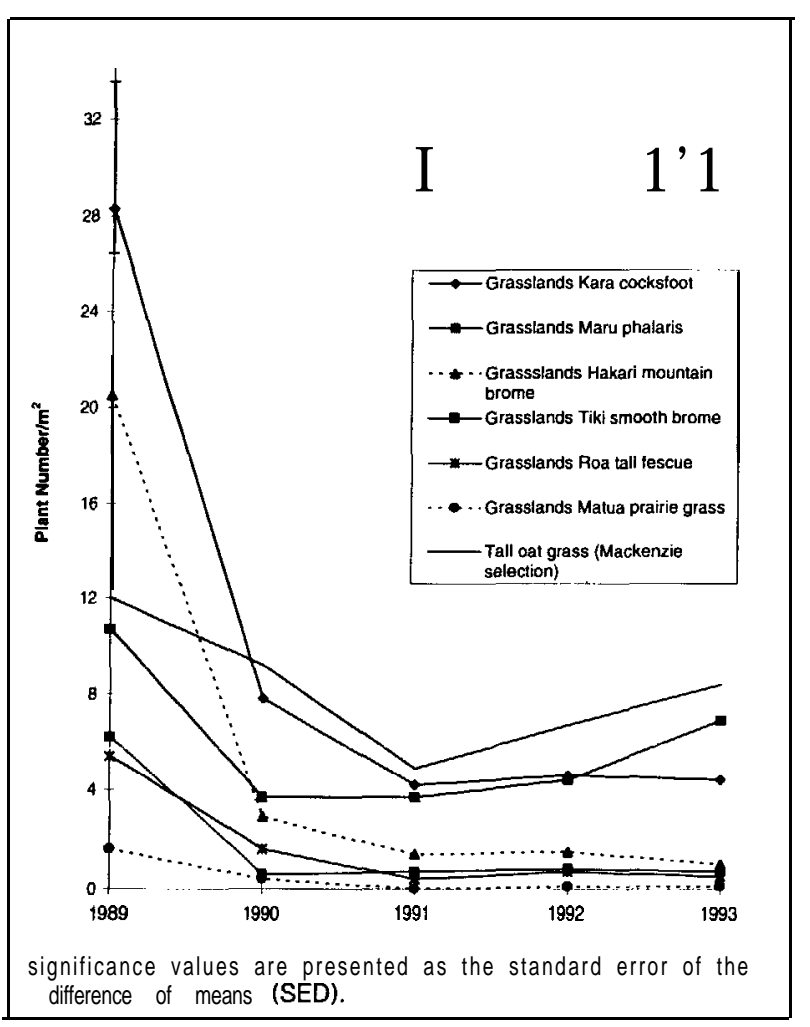

generally limited to the more favourable soil conditions within the old stream channels.

The poor survival of perennial lupin seedlings during establishment was probably a consequence of non-inoculation of the seed before sowing rather than an inadequate sowing rate (Scott 1989). Although stands of perennial lupin from uninoculated seed occurred nearby, in hindsight, seed should have been inoculated with the recommended Bradyrhizobium strain of rhizobia NZP 2141 to ensure successful establishment and rapid development of the stand.

Grasslands Pawera red clover was inferior to the New Zealand birdsfoot trefoil cultivars. Its dramatic decline in plant numbers 4-5 years after sowing can be attributed to the severe drought in spring 1989 and following dry summer. It did not re-establish from seed. Red clover has low persistence in drought-prone sub-humid environments (500-800 mm) (e.g., Greenwood \& Sheath 1982). Similarly, lucerne had poor persistence and vigour because the subsoil acidity complex restricted root growth and penetration to zones of soils in which water potential remains adequate under dry conditions (Douglas 1985).

Birdsfoot trefoil is reported to have a low $\mathrm{P}$ requirement (Davis 1991) and is considered to be a long-lived perennial legume under lax grazing (Woodman et al. 1992). However, on

Figure 4 Survival of perennial lupin seedlings (as a percentage of seedlings marked in October 1993).

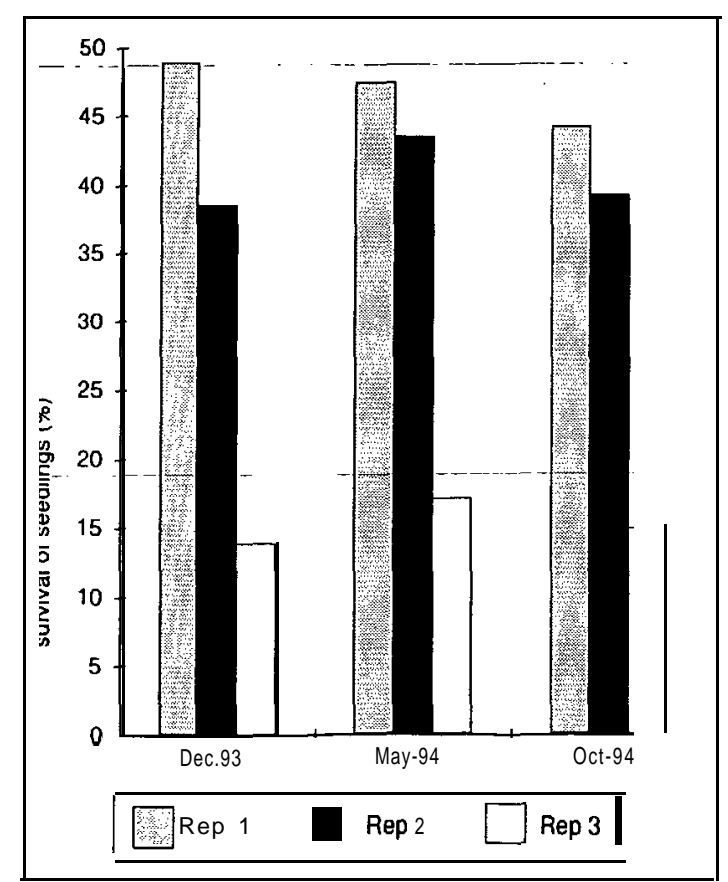

these outwash plains, plant populations of various cultivars of birdsfoot trefoil declined prematurely, particularly in areas of lesser soil fertility and associated higher-subsoil-aeidity;Some cultivars-(including-Grass= lands Goldie) are recognised as being only moderately tolerant of soil acidity (Belesky et al. 1991), while others may be only marginally more tolerant of soluble soil aluminium than lucerne (Baligar et al. 1984). It has been reported that the subsoils of high country yellowbrown earths can prevent the formation of a tap-root in birdsfoot trefoil (Davis 1991), thus conferring a lesser ability to source subsoil moisture, whereas the development of a stout tap-root in perennial lupin was unrestricted under the same conditions. Previous reports of poor performance of deep-rōted legumes on droughty, shallow soils with underlying parent rock material (Woodman et al. 1992) can also be attributed to rooting depth constraints.

Declining populations of birdsfoot trefoil are indicators of poor plant recruitment from reseeding. Birdsfoot trefoil is a summer-producing legume (Scott $\&$ Charlton 1983) which requires a 16 -hour photoperiod for full flowering (Seaney \& Hansen 1970). In the southern Mackenzie Basin, flowering in birdsfoot trefoil cannot start until late December or January, with 
indeterminate flowering throughout the remainder of the summer. In addition, seeds require 30-34 days after flowering to attain satisfactory viability (Li \& Hill 1989). However, by November there is often a soil moisture deficit on the flats, and the expectation of a successful reproductive sequence under these stressful environmental conditions is slight and is reflected in these results. The selection and breeding of populations with a shorter photoperiod requirement may be necessary for summer-dry areas if natural plant recruitment is to be considered essential for birdsfoot trefoil stand longevity.

Plant recruitment by reseeding was successful in perennial lupin in most years and this maintained the longevity of the stand. Compared with birdsfoot trefoil, perennial lupin requires a relatively shorter photoperiod for full flowering (Scott 1989), starting in the southern Mackenzie Basin in early to mid November and finishing in late November or early December when subsoil moisture is still adequate for successful flowering and completion of the reproductive sequence.

Most germination and emergence of perennial lupin at this site occurs in late winter-early spring at soil temperatures below $5^{\circ} \mathrm{C}$ and earlier than any other pasture legume. Rapid seedling establishment can be attributed to the large seed reserves (Davis 1981) and seedling development and establishment benefits from the high proportion of open ground. Competition for moisture and nutrients becomes less important as the lupin tap-root quickly develops, the primary roots extending sufficiently rapidly to maintain continuing contact with the diminishing moisture front in the soil during spring.

\section{Conclusions}

Connie perennial lupin is a suitable pasture legume alternative on droughty, infertile, acidic outwash soils in the southern Mackenzie Basin. Plant populations have increased with time through seedling recruitment.

New Zealand cultivars of birdsfoot trefoil and Granger from the USA are persistent pasture legumes within the more favourable parts of the soil mosaic, but lack the ability to regenerate to ensure stand longevity.

Grasslands Pawera red clover and WL318 lucerne are unsuited to this environmement.

\section{ACKNOWLEDGEMENTS}

Mr Dick Wardell for providing the experimental site and grazing managment.

\section{REFERENCES}

Baligar, V.C.: Bennett, O.L.; Kinraide, T.B.; Wright, R.J. 1984. Growth responses of forage species to aluminium. 48th annual report of forage research in North-eastern United States.

Belesky, D.P.; Fedders, J.M.; Wright, R.J. 1991. Shortterm bioassay of Lotus corniculatus soil acidity tolerance. pp. 931-938.In: Wright, R.J.et al. (eds.). Plant-soil interactions at low $\mathrm{pH}$. Netherlands: Kluwer Academic Publishers.

Cornforth, I.S. 1984: Soil testing. pp. 9. In: Cornforth, I.S.; Sinclair, A.G. (eds.). Fertilizer Recommendations for Pastures aand Crops in New Zealand. Wellington, New Zealand: Ministry of Agriculture and Fisheries.

Davis, M.R. 1981. Growth and nutrition of legumes on a high country yellow-brown earth subsoil I. Phosphate response of Lotus, Trifolium, Lupinus, Astragalus and Coronilla species and cultivars. New Zealand journal of agricultural research 24: 321332.

Davis, M.R. 1991. The comparative phosphorus requirements of some temperate perennial legumes. Plant and soil 133: 17-30.

Douglas, M.H. 1985. Lucerne establishment on high country soils. Proceedings of the 1985 Hill and High Country Seminar. Lincoln College Centre or Resource Management, Lincoln College, special publication no. 4: 45-49.

Greenwood, P.B.; Sheath, G.W. 1982. Suitability of some pasture species within sub-humid areas of Otago 2. Legumes. New Zealand journal of experimental agriculture 10: 371-376.

Li, Q.; Hill, M.J. 1989. Seeddevelopment and dormancy characteristics in Lotus corniculatus L. New Zealand journal of agricultural research 32: 333-336.

Scott, D. 1989. Perennial or Russel lupin: A potential high country pasture legume. Proceedings of the New Zealand Grass/and Association 50: 203-206.

Scott, D.; Charlton, J.F.L. 1983. Birdsfoot trefoil (Lotus corniculatus) as a potential dryland herbage legume in New Zealand. Proceedings of the New Zealand Grassland Association 44: 98-105.

Scott, D.; Maunsell, L.A.; Hunt, L.M. 1994. Relative sheep liveweight gain on perennial lupin, red clover and alsike. Proceedings of the New Zealand Grassland Association 56: 155-I 58.

Seaney, R.R.; Henson, P.R. 1970. Birdsfoot trefoil. Advances in agronomy 22: 119-I 57.

Webb, T.H., 1992. Soils of the Upper Waitaki Basin, South Island, New Zealand. DSIR Land Resources Scientific Report No. 3.

Woodman, R.F.; Keoghan, J.M.; Allan, B.E. 1992. Pasture species for drought-prone lower slopes in the South Island high country. Proceedings of the New Zealand Grassland Association 54: 115-I 20. 